\title{
The Effect of Gibberellin (GA3) Concentration on The Growth of Sugarcane Orchid (Grammatophyllum speciosum) Protocorm in Vitro
}

\author{
Elly Roosma Ria ${ }^{1}$, Reni Nurhayatini' ${ }^{2}$, Yesi Agustin ${ }^{3}$ \\ \{ellyroosmaria@unwim.ac.id ${ }^{1}$,renimuljadi@gmail.com ${ }^{2}$ \} \\ Departement of Agrotechnology, Faculty of Agriculture, Winaya Mukti University \\ Tanjungsari, Sumedang, Indonesia
}

\begin{abstract}
The purpose of the experiment was to study the effect of gibberellin $\left(\mathrm{GA}_{3}\right)$ concentration on the growth of sugarcane orchid (Grammatophyllum speciosum) protocorm in vitro. The experiment was conducted at the laboratory of Winaya Mukti University, from May 2018 until August 2018. The design was used a Completely Randomized Design (CRD) with five treatments and five replications. The concentrations were tested : $\mathrm{A}=0 \mathrm{mg} \mathrm{L}^{-1}$ (without $\mathrm{GA}_{3}$ ), $\mathrm{B}=5 \mathrm{mg} \mathrm{L}^{-1}$ solution of $\mathrm{GA}_{3}, \mathrm{C}=10 \mathrm{mg} \mathrm{L}^{-1}$ solution of $\mathrm{GA}_{3}, \mathrm{D}=15 \mathrm{mg} \mathrm{L}^{-1}$ solution of $\mathrm{GA}_{3}, \mathrm{E}=20 \mathrm{mg} \mathrm{L}^{-1}$ solution of $\mathrm{GA}_{3}$. The result of the experiment showed that the concentration of gibberellin $\left(\mathrm{GA}_{3}\right)$ have an effect on the growth of sugarcane orchid (Grammatophyllum speciosum) protocorm in vitro. Giving $5 \mathrm{mg} \mathrm{L}^{-1}$ solution of $\mathrm{GA}_{3}$ have an effect on the plant height of $12 \mathrm{WAC}$ (Weeks After Culture).
\end{abstract}

Keywords : Sugarcane Orchids, Gibberellin, In Vitro

\section{Introduction}

Orchid production in 2017 amounted to 20,045 million stalks, followed by chrysanthemums with production of 480.68 million stalks, roses with a production of 184.46 million stalks, and delicious night with production of 112.29 million stalks [1]. Cane orchids are rare orchids. Sugarcane orchid is the largest and most heavily orchid among other orchid species [2]. Sugarcane orchids also have attractive shapes and colors because there are brown spots that appear to contrast with the base color of the yellow color. In addition, this orchid flower can last long and not easily wither. Tissue culture is a technique for developing aseptic and accent in parts of plants in vitro on culture media containing complete nutrients and controlled environmental conditions for specific purposes [3]. The use of tissue culture techniques carried out so far is considered effective enough to develop quality and uniform seeds for various types of plants (potted plants, cut flowers, fruit plants, and tuber plants). Gibberellin is a growth regulating agent that is useful for plants, in low concentrations it can stimulate cell division and elongation. The response of plants that often arise due to gibberellic activity is an increase in cell elongation, especially in the stem [4]. Gibberellin effect not only encourage the extension of the rod, but is also involved in the regulation of developmental processes of plants such as auxin. 
The purpose of this research is studying the effect of concentration of gibberellins $\left(\mathrm{GA}_{3}\right)$ on growth protocorm sugarcane orchid in vitro. To determine the concentration of gibberellin (GA3) which provides the most good influence on the growth of sugarcane protocorm orchid in vitro.

\section{Research Methods}

The experiment was conducted at Tissue Culture Laboratory, Faculty of Agriculture, University of Winaya Mukti, Tanjungsari, Sumedang, West Java with altitude of 878 meters above sea level. The room temperature is $24 \mathrm{oC}$ and humidity of $71 \%$. Materials used during the trial include orchid protocorm sugarcane, gibberellin (GA3), MS medium (Murashige and Shoog) + vitamin, sugar, gelatin powder. This experiment used a Completely Randomized Design (CRD) with 5 treatments and 5 replications as : A $=0 \mathrm{mg} \mathrm{L}-1$ solution (without GA3), $\mathrm{B}=5 \mathrm{mg}$ L-1 GA3 solution, $\mathrm{C}=10 \mathrm{mg}$ L-1 GA3 solution, $\mathrm{D}=15 \mathrm{mg}$ L-1 GA3 solution, and $\mathrm{E}=20 \mathrm{mg} \mathrm{L}-1 \mathrm{GA} 3$ solution. The variables observed consist of plant height, number of leaves, number of roots, root length, and plant wet weight.

The experiment was carried out by adding $20 \mathrm{ml}$ of liquid media (MS, sugar and GA3) into a bottle containing 3 protocorms.

\section{Result and Discusion}

\subsection{Root Length}

Table 1. The Effect of Gibberellin $\left(\mathrm{GA}_{3}\right)$ Concentration on Root Length at 12 WAC

\begin{tabular}{ccc}
\hline Treatments & \multicolumn{2}{c}{ Root Length (mm) } \\
\hline $\mathrm{A}\left(0 \mathrm{mg} \mathrm{L}^{-1} \mathrm{GA}_{3}\right.$ solution $)$ & 9.78 & $\mathrm{~b}$ \\
$\mathrm{~B}\left(5 \mathrm{mg} \mathrm{L} \mathrm{GA}_{3}\right.$ solution $)$ & 3.12 & $\mathrm{a}$ \\
$\mathrm{C}\left(10 \mathrm{mg} \mathrm{L}^{-1} \mathrm{GA}_{3}\right.$ solution $)$ & 2.12 & $\mathrm{a}$ \\
$\mathrm{D}\left(15 \mathrm{mg} \mathrm{L}^{-1} \mathrm{GA}_{3}\right.$ solution$)$ & 1.18 & $\mathrm{a}$ \\
$\mathrm{E}\left(20 \mathrm{mg} \mathrm{L}^{-1} \mathrm{GA}_{3}\right.$ solution $)$ & 3.77 & $\mathrm{ab}$ \\
\hline
\end{tabular}

Description: The figure marked the same letter show no significant according to Duncan's Multiple Range Test at $5 \%$ level.

Root length increase is caused by the process of cell division in the root end meristem, followed by the process of elongation and cell division [5]. The inhibiting factor of cell elongation can occur with a large number of concentrations, the function of gibberellins at low concentrations does not stimulate the extension of moderate roots with high concentrations can stimulate root lengthening [6]. 


\subsection{Number of Roots}

Table 2. The Effect of Gibberellin $\left(\mathrm{GA}_{3}\right)$ Concentration on Number of Root at $12 \mathrm{WAC}$

\begin{tabular}{|c|c|c|}
\hline Treatments & \multicolumn{2}{|c|}{ Number of Root (pcs) } \\
\hline $\mathrm{A}\left(0 \mathrm{mg} \mathrm{L}^{-1} \mathrm{GA}_{3}\right.$ solution $)$ & 1.11 & a \\
\hline $\mathrm{B}\left(5 \mathrm{mg} \mathrm{L}^{-1} \mathrm{GA}_{3}\right.$ solution $)$ & 1.06 & a \\
\hline $\mathrm{C}\left(10 \mathrm{mg} \mathrm{L}^{-1} \mathrm{GA}_{3}\right.$ solution $)$ & 1.03 & $\mathrm{a}$ \\
\hline $\mathrm{D}\left(15 \mathrm{mg} \mathrm{L}^{-1} \mathrm{GA}_{3}\right.$ solution $)$ & 1.00 & $\mathrm{a}$ \\
\hline $\mathrm{E}\left(20 \mathrm{mg} \mathrm{L}^{-1} \mathrm{GA}_{3}\right.$ solution $)$ & 1.00 & a \\
\hline
\end{tabular}

Description: The figure marked the same letter show no significant according to Duncan's Multiple Range Test at $5 \%$ level.

Low concentration of gibberellins giving a bad effect, this is presumed because roots synthesize exogenous gibberellins, but endogenous gibberellins cause little effect on root growth and will inhibit root growth [7]. Gibberellins stimulate the leaves and stems, but the effects on root growth slightly so that the endogenous gibberellin given are not capable of stimulating the roots of the wild. Orchid plants enough sunlight will develop better roots, more root number, size and branching. At low concentrations (according to plant needs), gibberellins can stimulate root growth, while at high concentrations, it will inhibit the rate of elongation of the coleoptile (root tip) and stem. This is due to start at the loss of turgor pressure in the cell wall [8].

\subsection{Root Length}

This is due to endogenous gibberellin activity stimulated by exogenous gibberellins resulting in increased cell metabolic activity. Metabolic processes will spur cell division and enlargement so that it grows elongated and enlarged. Growth in plant height will also be affected by light intensity. Low light intensity can stimulate endogenous growth regulators to work more actively in the process of plant growth and development [9]. GA3 can stimulate stem growth, increase the magnification and multiplication of cells in plants, so the plants can reach the maximum height $[10]$ 
Table 3. The Effect of Gibberellin $\left(\mathrm{GA}_{3}\right)$ Concentration on Plant Height at $12 \mathrm{WAC}$

\begin{tabular}{lcc}
\hline \multicolumn{1}{c}{ Treatments } & \multicolumn{2}{c}{ Plant Height $(\mathrm{mm})$} \\
\hline $\mathrm{A}\left(0 \mathrm{mg} \mathrm{L}^{-1} \mathrm{GA}_{3}\right.$ solution $)$ & 9.00 & $\mathrm{a}$ \\
$\mathrm{B}\left(5 \mathrm{mg} \mathrm{L}^{-1} \mathrm{GA}_{3}\right.$ solution $)$ & 56.67 & $\mathrm{~b}$ \\
$\mathrm{C}\left(10 \mathrm{mg} \mathrm{L}^{-1} \mathrm{GA}_{3}\right.$ solution $)$ & 34.67 & $\mathrm{ab}$ \\
$\mathrm{D}\left(15 \mathrm{mg} \mathrm{L}^{-1} \mathrm{GA}_{3}\right.$ solution $)$ & 6.73 & $\mathrm{a}$ \\
$\mathrm{E}\left(20 \mathrm{mg} \mathrm{L}^{-1} \mathrm{GA}_{3}\right.$ solution $)$ & 16.07 & $\mathrm{a}$ \\
\hline
\end{tabular}

Description: The figure marked the same letter show no significant according to Duncan's Multiple Range Test at 5\% level.

\subsection{Number of Leaves}

Table 4. The Effect of Gibberellin $\left(\mathrm{GA}_{3}\right)$ Concentration on Number of Leaves at 4 WAC, 8 WAC and 12 WAC

\begin{tabular}{|c|c|c|c|c|c|c|}
\hline \multirow{2}{*}{ Treatments } & \multicolumn{6}{|c|}{ Number of Leaves (strands) } \\
\hline & \multicolumn{2}{|c|}{$4 \mathrm{WAC}$} & \multicolumn{2}{|c|}{$8 \mathrm{WAC}$} & \multicolumn{2}{|c|}{$12 \mathrm{WAC}$} \\
\hline $\mathrm{A}\left(0 \mathrm{mg} \mathrm{L}^{-1} \mathrm{GA}_{3}\right.$ solution $)$ & 0.00 & $\mathrm{a}$ & 0.93 & $\mathrm{~A}$ & 1.47 & $\mathrm{a}$ \\
\hline $\mathrm{B}\left(5 \mathrm{mg} \mathrm{L}^{-1} \mathrm{GA}_{3}\right.$ solution $)$ & 0.00 & $\mathrm{a}$ & 0.80 & A & 1.13 & $\mathrm{a}$ \\
\hline $\mathrm{C}\left(10 \mathrm{mg} \mathrm{L}^{-1} \mathrm{GA}_{3}\right.$ solution $)$ & 0.00 & $\mathrm{a}$ & 0.67 & A & 1.00 & $\mathrm{a}$ \\
\hline $\mathrm{D}\left(15 \mathrm{mg} \mathrm{L}^{-1} \mathrm{GA}_{3}\right.$ solution $)$ & 0.00 & $\mathrm{a}$ & 0.60 & A & 0.93 & $\mathrm{a}$ \\
\hline $\mathrm{E}\left(20 \mathrm{mg} \mathrm{L}^{-1} \mathrm{GA}_{3}\right.$ solution $)$ & 0.00 & $\mathrm{a}$ & 0.53 & A & 0.87 & $\mathrm{a}$ \\
\hline
\end{tabular}

Description: The figure marked the same letter show no significant according to Duncan's Multiple Range Test at $5 \%$ level.

The temperature factor directly affects the growth of cells and tissues, the formation of plant organs, and are associated with the development cycle of the plant which is under the influence of enzymes. The effect of temperature is more critical in in vitro culture than in vivo culture. This is due to the sensitive nature of the network and the lack of a network protection mechanism [11]. The intensity of light has an effect on triggering leaf growth because leaves are one of the organs that are very important especially for photosynthesis so that plants can produce food and experience optimum growth [12].

\subsection{The Weight of Plant Wet}


Table 5. The Effect of Gibberellin $\left(\mathrm{GA}_{3}\right)$ Concentration on The Weight of Plant Wet at $12 \mathrm{WAC}$

\begin{tabular}{lrl}
\hline Treatments & The Weight of Plant Weight $(\mathrm{mg})$ \\
\hline $\mathrm{A}\left(0 \mathrm{mg} \mathrm{L}^{-1} \mathrm{GA}_{3}\right.$ solution $)$ & 56.00 & $\mathrm{a}$ \\
$\mathrm{B}\left(5 \mathrm{mg} \mathrm{L} \mathrm{GA}_{3}\right.$ solution $)$ & 40.80 & $\mathrm{a}$ \\
$\mathrm{C}\left(10 \mathrm{mg} \mathrm{L}^{-1} \mathrm{GA}_{3}\right.$ solution $)$ & 30.00 & $\mathrm{a}$ \\
$\mathrm{D}\left(15 \mathrm{mg} \mathrm{L}^{-1} \mathrm{GA}_{3}\right.$ solution $)$ & 26.60 & $\mathrm{a}$ \\
$\mathrm{E}\left(20 \mathrm{mg} \mathrm{L}^{-1} \mathrm{GA}_{3}\right.$ solution $)$ & 34.00 & $\mathrm{a}$ \\
\hline
\end{tabular}

Description: The figure marked the same letter show no significant according to Duncan's Multipl Range Test at $5 \%$ level.

The fresh weight of plants is related to plant leaf area, increasing photosynthesis causes wider leaf area so that leaves can absorb sunlight more optimally and other metabolic processes can run [13]. The wet weight of the plant is the amount of water content inside the plant's organ, in addition to the organic matter. Wet weight shows how metabolic processes occur in plants. The level of plant wet weight is influenced by the water content found in plant tissues or organs, nutrients, and organic matter contained in a plant [14].

\section{Conclusion}

Based on the results of experiments on the effect of gibberellin concentration on the growth of sugarcane orchid protocorm in vitro, it can be concluded that the concentration of gibberellin (GA3) affects the growth of sugarcane orchid protocorm in vitro at the age of 12 WAC (Week after Culture). Concentration of $5 \mathrm{mg} \mathrm{L}-1$ GA3 solution had a good effect on plant height at 12 WAC.

\section{Reference}

[1] Central Bureau of Statistics. 2017. International Trade in Ornamental Plants. Accessed from www.Bps.Go.Id October 10, 2018

[2] Rimando, Tito J. 2001. Ornamental Horticulture A Little Giant in The Tropics. SEAMO SEARCA and UPLB. Philipines. $99 \mathrm{p}$

[3] George, F. P. and Sherrington P. D. 1984. Plant Propagation by Tissue Culture. Eversley: Hand Book and Directory of Commercial Laboratories Exigetic Limited.

[4] Salisbury, F.B. and C.W. Ross. 1995a. Plant Physiology. Plant Biochemistry, Volume 2. Translators: Lukman D.R and Sumaryono. ITB Publisher. Bandung.

[5] Widiastoety, D. 2014. Effect of Auxin and Cytokinin on the Growth of Mokara Orchid Plantlets. J Hort 24(3) :230-238. 2014. Ornamental Crops Research Institute. Jl. Raya Ciherang-Pacet Cianjur 
[6] Amelia. 2009. Hormonal (Plant Hormone). Quoted from http://blogspot.com/hijauque.html.accessed on March 15, 2018.

[7] Yos Sutiyoso, 2003. Orchid Dendrobium. Penebar Swadaya: Jakarta

[8] Sriyanti, D. H. 2000. Orchid Breeding in Bottles. Kanisius Yogyakarta.

[9] Wattimena G A. 1988. Growth Regulating Substances. Bogor (ID): Inter-University Center of IPB. $247 \mathrm{p}$.

[10] Prawiranata, W.S. Harran and P. Tjondronegoro. 1981. Basics of Plant Physiology II. Faculty of Agriculture, Bogor

[11] Zulkarnain. 2009. Plant Tissue Culture: Solution to Propagation of Cultivation Plants. Earth Literature. Jakarta

[12] Sylvia, I. 2009. Effect of IBA and NAA on Donna Carmen's Aglonema Var Cuttings with Immersion. Thesis of the Faculty of Agriculture, Bogor Agricultural University

[13] Sitompul, S. M and B. Guritno. 1995. Analysis of Plant Growth. UGM Press Yogyakarta.

[14] Mudyantini, W. 2008. Growth, Cellulose, and Lignin Content in Flax (Boehmeria nivea L.Gaudich) by Giving Giberellic Acid (GA). Available at: http://biodiversitas.mipa.uns.ac.id/. Accessed September 10, 2018 